
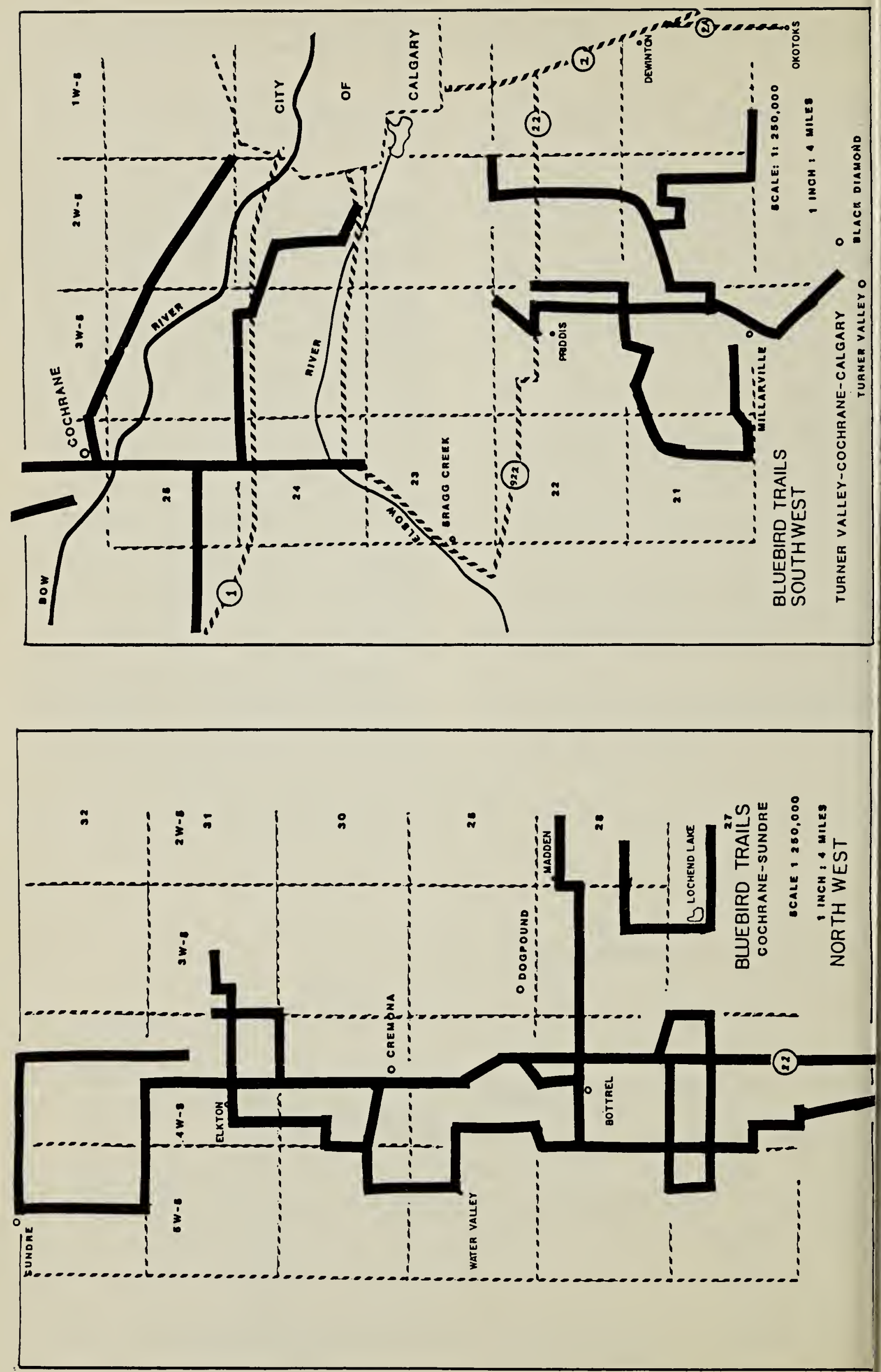
Table 1. CALGARY AREA NESTBOX RESULTS - 1983

\begin{tabular}{|c|c|c|c|c|c|c|}
\hline & Southwes & $\begin{array}{l}\text { Blake } \\
\text { Stillings }\end{array}$ & Northwest & Northeast & $\begin{array}{l}\text { Seebe- } \\
\text { Canmore }\end{array}$ & Totals \\
\hline No. of Boxes & 223 & 301 & 151 & 103 & 39 & 817 \\
\hline Miles of Line & 121 & 168 & 94 & 65 & 21 & 469 \\
\hline \multicolumn{7}{|l|}{ Mountain Bluebird } \\
\hline No. Nests & 50 & 141 & 37 & 47 & 2 & 277 \\
\hline$\%$ Successful & 76 & 91 & $92 \mathrm{e}^{*}$ & 66 & 100 & $84 \mathrm{e}$ \\
\hline No. Eggs & 244 & 719 & 203 & 250 & 13 & 1429 \\
\hline No. Young Fledged & 183 & 641 & $150 \mathrm{e}$ & 156 & 13 & $1143 e$ \\
\hline Clutch Size & 4.88 & 5.10 & 5.49 & 5.32 & 6.5 & 5.16 \\
\hline Y/Successful N & 4.82 & 5.01 & $4.41 \mathrm{e}$ & 5.03 & 6.5 & $4.90 \mathrm{e}$ \\
\hline Banded & 19 & & 87 & 30 & & 136 \\
\hline \multicolumn{7}{|l|}{ Tree Swallow } \\
\hline No. Nests & 145 & 186 & 94 & 53 & 5 & 483 \\
\hline$\%$ Successful & 85 & 98 & $81 \mathrm{e}$ & 79 & 80 & $88 \mathrm{e}$ \\
\hline No. Eggs & 777 & 1104 & 513 & 294 & 29 & 2717 \\
\hline No. Young Fledged & 648 & 1018 & $372 \mathrm{e}$ & 204 & 22 & $2264 \mathrm{e}$ \\
\hline Clutch Size & 5.36 & 5.94 & 5.46 & 5.55 & 5.8 & 5.62 \\
\hline Y/Successful N & 5.27 & 5.59 & $4.89 \mathrm{e}$ & 4.86 & 5.5 & $5.32 \mathrm{e}$ \\
\hline Banded & 32 & & 113 & 91 & & 236 \\
\hline House Sparrow & 10 & 12 & 6 & 13 & 0 & 41 \\
\hline House Wren & 14 & 3 & 3 & 4 & 0 & 24 \\
\hline Multiple Use & 21 & 27 & 9 & 18 & 0 & 75 \\
\hline Vandalized & 11 & 25 & 5 & 2 & 0 & 43 \\
\hline Boxes Not Used & 13 & 2 & 8 & 4 & 28 & 55 \\
\hline
\end{tabular}

${ }^{*} \mathrm{e}=$ estimated

On this trail every time the number of bluebird nests increased the number of Tree Swallows decreased and vice versa. This is true in almost all cases.

Eleven new boxes in the Lochend Lake area plus five put up by someone unknown had only swallows but are within $4 \mathrm{mi}$. of trail with bluebirds and are in good habitat.

\section{New Bluebirds}

Bluebird range extension was reported by Jim Minty $4 \mathrm{mi}$. south and 1 mi. west of Strathmore where boxes only had swallows and House Sparrows previously. The nearest known bluebirds are at Rosebud $30 \mathrm{mi}$. northeast, although some may nest along the Bow River $12 \mathrm{mi}$. south.

Five new houses on the west Dewinton trail had four bluebird nests and an extension of the West Crossfield trail produced four bluebird nests in an area where in the past 3 years there were only swallows.

Table 2. PRIDDIS-MILLARVILLE TRAIL RESULTS OVER 6 YEARS

\# of Nests

$\begin{array}{lcccccc} & 1978 & 1979 & 1980 & 1981 & 1982 & 1983 \\ \text { Bluebirds (first broods only) } & 18 & 21 & 10 & 11 & 17 & 19 \\ \text { Tree Swallows } & 11 & 12 & 23 & 22 & 17 & 13\end{array}$




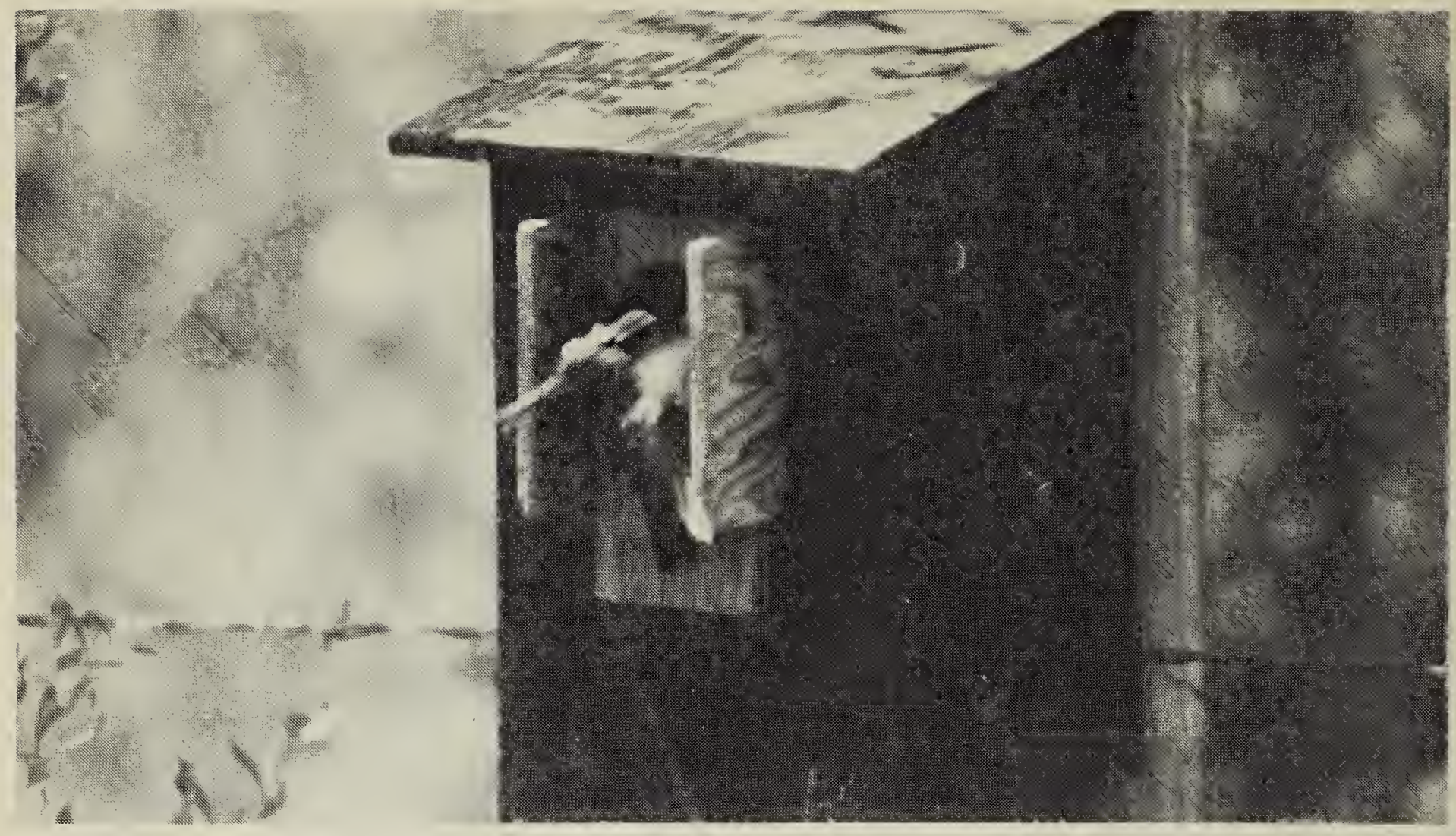

Tree Swallow by-passing wing guards.

Kay Morck

\section{Swallow Wing Guards}

In an experimental project of the North American Bluebird Society plywood strips 1.75 " wide were attached to the fronts of nest boxes 2.5" apart. These were supposed to impede the Tree Swallow who has to keep fluttering its wings right up to landing whereas the bluebird is supposed to be able to fold its wings before reaching the hole to land.

Kay Morck tried one of these but Tree Swallows still used the box. She photographed a Tree Swallow entering the nest by outwitting the guard. Stiles tried two wing guards; bluebirds nested where one was and later swallows tried unsuccessfully. In the second box bluebirds only fledged one of five young; the others died when half grown. The wing guards were placed on a House Sparrow - prone box with an extra 1.5" plywood over the hole. Sparrows still used the box. (Monitors now usually remove nest boxes repeatedly used by sparrows.)

The North American Bluebird Society reported only about $50 \%$ success with the swallow wing guards.

\section{Highlights}

Mike Stanfield near Priddis reported: "We have bluebirds nesting in a pole box on the edge of our front lawn every year; this year the 26th June was the day when five fledglings left the nest... Today (June 28) a dead mature male was found deposited at the back door by a cat. In the evening there was a terrific chasing and pecking and fluttering going on in the garden by the box, a blue blurr of wings and feathers, only a few feet away from where I stood. After some fifteen minutes I got tired and left, but these birds kept right on at it until they became quite exhausted, fluttering down on the grass, breathless. I was watching from the window for another 15 minutes until it was dusk. I finally determined that two mature females were fighting over one mature male. The male and one female would go into the box, and then out again; he would flutter his wings at her, then chase the other one away, then all three would fight, spiralling round each other and falling repeatedly down to the grass, rather like butterflies spiral around. No second brood occurred in spite of all this!" 
Ray Woods reported an instance of some missing young. "In one instance this summer 6 young were counted in a nest on June 12th. These young were brand new and too young to band. On returning a week later - June 19th -only 3 young were in the nest! Could the other three have been thrown out by a parent? If so, how often does this happen, I wonder?"

Bryan Shantz of Ellis Bird Farm northeast of Red Deer joined us for our annual monitors' reporting evening. He and Hazel monitor about 500 boxes, and band bluebirds wherever possible. He reports $27 \%$ of adult males and $37 \%$ of adult females return, usually within $1 \mathrm{mi}$. of their nesting site, but only $5 \%$ of young return the next year. He reported that driving rains caused the loss of one third of the Tree Swallows and some bluebirds with young aged 3 to 10 days at risk. Rains may explain in part variations between one monitor and the next, as several Calgary area monitors reported at least some dead young. Bryan reported tht Mountain Bluebirds take 14 days to incubate, and 20 days to fledge, but a shorter time, say 17 days if disturbed.

Nancy Murray reported four successful Mountain Chickadee nests. These may become the dominant species on her trail. Blake Stillings reported a successful Boreal Chickadee nesting and Bryan Shantz two Blackcapped Chickadee nests.

\section{Banding}

A total of 136 Mountain Bluebirds (26 adults plus 110 young) and 236 Tree Swallows (53 adults plus 183

\section{OUT OF PRINT SNHS S.P. \#5}

Special Publication No. 5 Birds of Lake Athabasca by R.W. Nero is out of print. young) were banded by Don, Philip and Andrew Stiles and Ray and Agnes Woods.

Band recoveries from 1982 were as follows:

- 2 adult bluebirds recovered of 16 banded $(12.5 \%)$

- 6 adult Tree Swallows recovered of 47 banded $(12.8 \%)$

- 1 Tree Swallow young of 131 banded $(0.08 \%)$.

The year-old Tree Swallow was one of a double brood of 12 banded in 1982 in box \#143 East Didsbury Trail (Blue Jay 40(4):205-206). Recoveries of the adult bluebirds were 0.5 and $1 \mathrm{mi}$. from their banding sites.

Two adult Tree Swallows banded in 1981 were recovered. Of the eight Tree Swallows recaptured two were in the same house, two moved $0.5 \mathrm{mi}$., two moved $1 \mathrm{mi}$., one moved $2.5 \mathrm{mi}$. and one moved $6 \mathrm{mi}$. from their banding sites, indicating that most birds return from migration to nest near their previous nesting site.

Two adult Tree Swallows were captured together from one nest and banded. On three occasions adults and young were banded in the same nest on the same date. Usually adults do not stay with young large enough to band (over about 6 days old).

Don Stiles banded two different females in the same nest for first and second broods of bluebirds, whereas Ray Woods found two occasions where the same bluebird female was recaptured in the same nest with a second brood.

\section{ERRATA}

FIRST SASKATCHEWAN RECORD OF CHANNEL CATFISH.

Edward L. Dean. December 1983 Blue Jay, page 183. Inadvertently the words "IN THE QU'APPELLE RIVER" were deleted from the title of this article. 